\title{
Age-Associated Changes in Bovine Growth Hormone Release via Human Growth Hormone-Releasing Factor
}

\author{
Koichi Hodate, Tetsu Johke, Asao Kawabata, \\ Hiroshi Fuse and Shinichi OHashi* \\ National Institute of Animal Industry, Tsukuba \\ Norindanchi Ibaraki-ken 305 \\ * Research Institute for Polymers \\ and Textiles, Tsukuba-shi 305
}

(Received September 10, 1987)

\begin{abstract}
Responses of growth hormone $(\mathrm{GH})$ release to synthetic human growth hormone-releasing factor-44- $\mathrm{NH}_{2}(\mathrm{hGRF}-44)$ in Holstein dairy cattle of various ages were compared. Blood samples of the experimental animals were taken from an indwelling catheter inserted into one of the external jugular veins before, and during a $90 \mathrm{~min}$ period following the injection of hGRF-44 $(0.25 \mu \mathrm{g}$ per $\mathrm{kg}$ of body weight). Plasma GH concentrations were measured by radioimmunoassay. Areas under GH response curves for the $90 \mathrm{~min}$ period after the hGRF-44 injection were determined and used as an index of the amount of GH released in response to this peptide. The $\mathrm{GH}$ releases of the experimental animals were significantly $(\mathrm{P}<0.01)$ stimulated by $h G R F-44$ injection in all cases. The magnitudes of $\mathrm{GH}$ release via $\mathrm{hGRF}-44$ were not significantly different between cattle from 6-12 hours to 6 months of age. On the other hand, the response in 12 month-old calves decreased significantly $(\mathrm{P}<0.05)$ as compared with that of the 6 month-old calves. Similarly, the response in heifers of 24 months of age decreased significantly $(\mathrm{P}<0.05)$ as compared with that of the calves of 12 months of age. Also, the response in 48 month-old dry cows was significantly $(\mathrm{P}<0.05)$ lower than that for 24 month-old heifers. These results indicate that somatotrophs of pituitary in just postnatal calves have an ability to respond to exogenous GRF, and pituitaries in cattle above 12 month-old exhibit a certain age-related decline in GH response to exogenous GRF.

Jpn. J. Zootech. Sci., 59 (3) : $285-291,1988$
\end{abstract}

Key words : age-associated change, growth hormone, hGRF-44, cattle

Synthetic human growth hormone-releasing factor-44- $\mathrm{NH}_{2}$ (hGRF-44) specifically stimulates the release of growth hormone $(\mathrm{GH})$ in several farm animals, i.e. cattle ${ }^{1-3}$, sheep $^{4-6)}$, goats ${ }^{1,5,7)}$, pigs ${ }^{4,8)}$ and chickens ${ }^{9,10)}$. In these animals, generally, there is a decline in the circulating basal level of $\mathrm{GH}$ with advancing age ${ }^{11-18)}$. Also, it appears that there is an age-related change in the response to stimuli of $\mathrm{GH}$ release. For example, it has been reported that the responses of $\mathrm{GH}$ release to exogenous thyrotropin releasing hormone (TRH) in heifers ${ }^{19)}$ and young fowl $\mathrm{s}^{18,20)}$ were greater than those in lactating cows and adult fowls, respectively. In previous studies, we also suggested that the $\mathrm{GH}$ responses to $\mathrm{hGRF}-44$ in cattle, sheep and goats decrease 
with age $e^{2,5)}$. In rats and humans, however, there is still controversy as to whether the response of GH to GRF decreases with age or not ${ }^{21-23)}$.

In the present experiments, we studied in order to get further information regarding the influences of age on the responses of GH release to synthetic hGRF-44 and on the basal levels of plasma GH in Holstein dairy cattle.

\section{Materials and Methods}

\section{Experimental animals}

Holstein dairy cattle from 6-12 hours to 58 months of age from the Institute herd were used. These animals were fed at $0830 \mathrm{~h}$.

Synthetic hGRF-44 for injection

The hGRF-44, synthesized by the solid-phase method and purified by HPLC ${ }^{24}$, was dissolved in 2-5 $\mathrm{m} l$ sterilized saline before use, and administered intravenously to each experimental animal through an indwelling catheter inserted into one of the external jugular veins between 1030 and $1130 \mathrm{~h}(2-3 \mathrm{hr}$ after feeding).

Blood sampling method

The collections of blood samples from the experimental animals were carried out throughout the year. The jugular venous blood was taken from an indwelling catheter previously inserted into one of the external jugular veins. Serial 3-5 $\mathrm{m} l$ blood samples were collected into centrifuge tubes containing heparin, and immediately chilled with ice. Individual plasma samples were obtained after centrifugation and stored at $-60^{\circ} \mathrm{C}$ until assayed.

Measurement of plasma GH and statistical analysis

The concentrations of plasma GH were determined by radioimmunoassay ${ }^{19}$. Areas under the GH response curves for $90 \mathrm{~min}$ af ter hGRF-44 injection were determined and used as an index of the amount of GH released in response to this peptide. The $t$-test ${ }^{25)}$ was used to assess the significance of the differences in the data.

Basal levels of plasma $\mathrm{GH}$ in relation to age

The basal levels of plasma GH in three 1 month-old male calves, $58 \mathrm{~kg}$ mean body weight (bw), four 6 month-old female calves, $199 \mathrm{~kg}$ mean bw, and four 58 month-old dry cows, $717 \mathrm{~kg}$ mean bw, were determined. The blood samples were drawn at 15 to $30 \mathrm{~min}$ intervals between 1015 and $1700 \mathrm{~h}$ of the day.

$\mathrm{GH}$ responses to hGRF-44 in relation to age

The responses of GH release to hGRF-44 $(0.25 \mu \mathrm{g}$ per $\mathrm{kg}$ of bw) in six neonates of 6-12 hours of age ( 3 female and 3 male; $38 \mathrm{~kg}$ mean bw), five 7 day-old calves ( 3 female and 2 male; $40 \mathrm{~kg}$ mean bw), eight 1 month-old female calves (59 kg mean bw), seven female calves of 4 months of age (129 kg mean bw), eight 6 month-old female calves ( $159 \mathrm{~kg}$ mean bw), seven 12 month-old female calves (344 kg mean bw), eight heifers of 24 months of age ( $429 \mathrm{~kg}$ mean bw), and six 48 month-old dry cows (672 kg mean bw) were compared. The blood samples were drawn at $-15,-10,0,5$, $10,15,20,30,45,60$, and 90 min after hGRF-44 injection. 


\section{Results}

Basal levels of plasma $\mathrm{GH}$ in relation to age

The mean plasma GH concentration in the 1 month-old calves varied within the range 6.9 to $30.7 \mathrm{ng} / \mathrm{ml}$ (Fig. 1), and the overall mean value was $15.7 \pm 1.7 \mathrm{ng} / \mathrm{m} l$ (mean $\pm \mathrm{SE} ; \mathrm{n}=16$ ). The mean plasma GH concentrations in the cattle of 6 and 58 months of age varied within the ranges 3.5 to $12.3 \mathrm{ng} / \mathrm{m} l$ and 2 to $3.9 \mathrm{ng} / \mathrm{ml}$ (Fig. 1), and the overall mean values were $5.9 \pm 0.6 \mathrm{ng} / \mathrm{m} l(\mathrm{n}=19)$ and $2.6 \pm 0.1 \mathrm{ng} / \mathrm{m} l(\mathrm{n}=16)$, respectively. The overall mean value of plasma $\mathrm{GH}$ in the 1 month-old calves was significantly $(\mathrm{P}<0.001)$ higher than that from the calves of 6 months of age. On the other hand, the overall mean value of $\mathrm{GH}$ in the cows of 58 months of age was significantly $(\mathrm{P}<0.001)$ low compared with that from the 6 month-old calves.

Thus, the basal plasma GH levels decreased with age.

GH responses to hGRF-44 in relation to age

The changes of plasma GH levels in cattle from 6-12 hours to 48 months of age in response to a single intravenous injection of hGRF-44 are shown in Fig. 2. Table 1 shows the areas under the $\mathrm{GH}$ response curves for $90 \mathrm{~min}$ after injection of the peptide.

The GH releases to hGRF-44 in the experimental animals were significantly $(\mathrm{P}<0.01)$ stimulated in all cases. The peak plasma $\mathrm{GH}$ values after hGRF-44 injection and the areas under the GH response curves were not significantly different

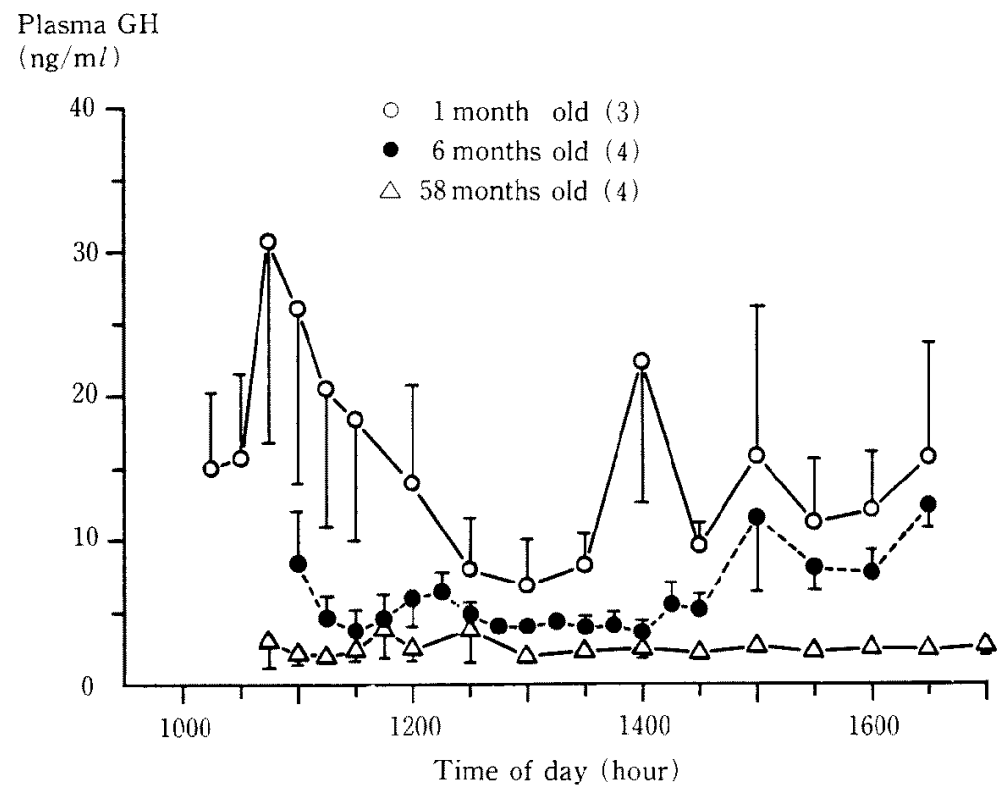

Fig. 1. Mean plasma GH levels in cattle of 1 month (O), 6 months $(-$ ) and 58 months $(\triangle)$ of age. Sampling was at 15 to 30 min intervals between 1015 and $1700 \mathrm{~h}$ of the day. Each point with a bar represents the mean $\pm \mathrm{SE}$. The figure in parentheses represents number of determinants. 

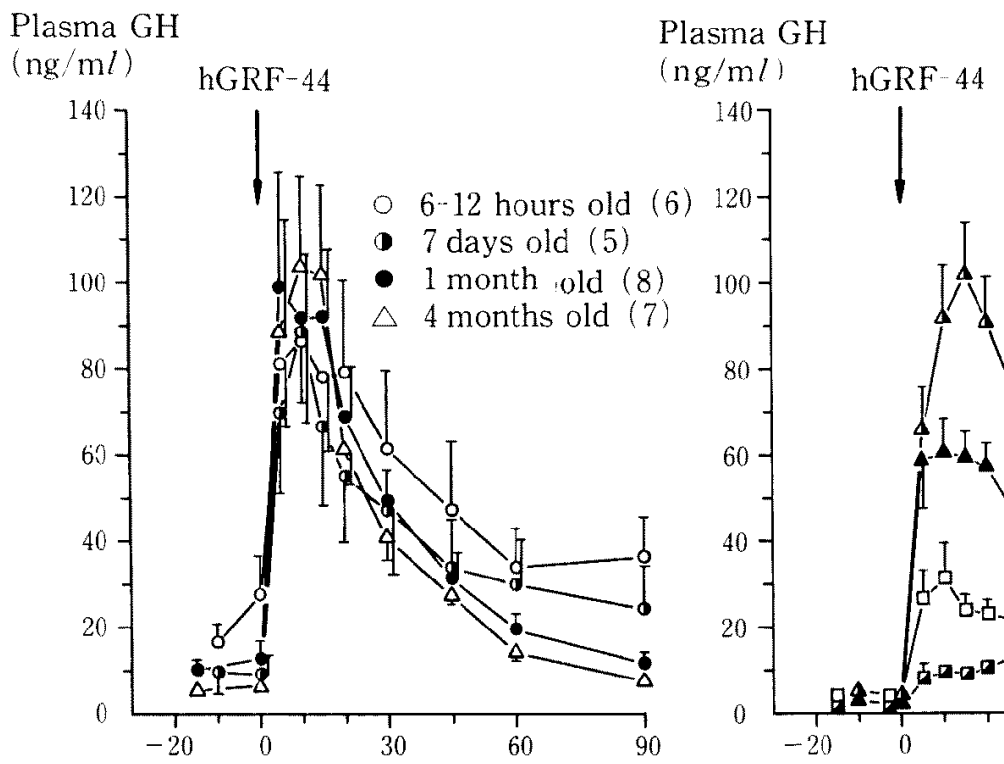

Time after injection $(\mathrm{min})$

Fig. 2. Plasma GH levels in response to a single intravenous injection of hGRF-44 $(0.25 \mu \mathrm{g}$ per $\mathrm{kg}$ of bw) in cattle of $6-12$ hours $(\bigcirc), 7$ days $(\mathbf{O}), 1$ month $(\mathbf{O}), 4$ months $(\triangle), 6$ months $(\mathbf{\Delta}), 12$

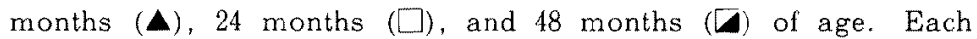
point with a bar represents the mean $\pm \mathrm{SE}$. The figure in parentheses represents number of determinants.

Table 1. Areas under $\mathrm{GH}$ response curves for $90 \mathrm{~min}$ after a single intravenous injection of hGRF-44 (0.25 $\mu \mathrm{g}$ per $\mathrm{kg}$ of bw) in cattle from 6-12 hours to 48 months of age.

\begin{tabular}{ccc}
\hline \hline Age & $\mathrm{n}$ & Areas $\left(\mathrm{ng} \cdot \min \cdot \mathrm{m} l^{\prime \prime}\right)$ \\
\hline 6-12 hours old & 6 & $4,673.4 \pm 1,125.1$ \\
7 days old & 5 & $3,695.7 \pm 992.1$ \\
1 month old & 8 & $3,683.5 \pm 683.6$ \\
4 months old & 7 & $3,231.5 \pm 484.3$ \\
6 months old & 8 & $4,079.9 \pm 455.0$ \\
12 months old & 7 & $2,798.7 \pm 247.9^{*}$ \\
24 months old & 8 & $1,662.7 \pm 250.1^{* * *}$ \\
48 months old & 6 & $745.3 \pm 64.3^{* * *}$ \\
\hline
\end{tabular}

The value is expressed as the mean $\pm \mathrm{SE}$. Asterisks indicate the statistical difference; ${ }^{*} \mathrm{P}<0.05,{ }^{* * *} \mathrm{P}<0.001$ as compared the with value of 6 months old calves.

between cattle from 6-12 hours to 6 months of age. In contrast, the peak plasma GH values and the areas in the cattle of 12,24 and 48 months of age were significantly ( $P$ $<0.05)$ lower than those obtained by the 6 month-old calves. Similarly, the peak values and the areas in the 24 and 48 month-old cattle were significantly $(P<0.05)$ lower than those from the calves of 12 months of age. The area in the 48 month-old 
cows was also significantly $(\mathrm{P}<0.05)$ low compared with that obtained by the 24 month-old heifers.

Thus, the responses of GH release to hGRF-44 in cattle above 12 month-old decreased significantly with increasing age.

\section{Discussion}

These data demonstrate that the somatotrophs of pituitary in the calves of 6-12 hours of age have an ability to respond to hGRF-44, and the pituitaries in cattle above 12 month-old exhibit a certain age-related decline in the GH response to hGRF-44. The former finding, as far as we know, has not yet been reported in cattle. The latter finding confirms the preliminary results ${ }^{2,5)}$ and extended. The present results also indicate that the basal level of plasma $\mathrm{GH}$ in cattle decreases with age. This result agreed with that of previous reports ${ }^{11,14,16,17)}$.

Since the pituitary in 6-12 hour-old calves exhibited to the responsiveness to hGRF-44 in the present study, the GH secretion in neonatal calves seems to be regulated by the hypothalamic GRF. COXAM et al. ${ }^{26)}$ reported that in 3 day-old calves the increase in plasma GH concentration by hGRF-44 was dose-related. In rats, hypothalamic GRF is critical in regulating serum GH concentrations in neonatal animals ${ }^{27}$. OHMURA et al. ${ }^{28)}$ reported that somatotrophs in fetal sheep in mid- and late gestation have receptors for GRF, because hGRF-40 markedly stimulated GH release in fetuses between 71 to 134 days of gestation, and suggested that ovine GH secretion may be modulated by GRF at this stage of gestation. GLucKmaN ${ }^{29)}$ also reported that the somatotroph in fetal sheep can respond to exogenous GRF from at least 77 days of gestation. It is not known whether somatotrophs in bovine fetuses have an ability to respond to exogenous GRF or not.

The reason for the decline in the bovine GH response to hGRF-44 and/or that in the basal plasma GH level with advancing age is not clear at the present time, but a decrease in endogenous GRF and an increase in somatostatin secretions may occur with advancing age. SHIzUmE et al. ${ }^{30)}$ demonstrated that there were a significant decrease in content of hypothalamic GRF and a significant increase in somatostatin content in old rats (24 to 28 month-old) as compared with those obtained in young rats ( 3 month-old), and that the secretion of hypothalamic GRF in the old rats decreases significantly as compared with that from the young rats, and suggested that an agerelated decline in rat $\mathrm{GH}$ secretion may be due to decreased hypothalamic GRF secretion. In addition, as other possible explanations, it may be that the sensitivity of bovine pituitary to GRF or somatostatin, i.e. number and affinity of GRF or somatostatin receptor, changes with age; the sensitivity of pituitary to GRF decreases, and the sensitivity to somatostatin increases with age. In rats, CEDA et al. ${ }^{312}$ observed that both in vivo and in vitro, the responses of GH release to hGRF44 in young animals ( 2 to 5 month-old) are larger than in aged animals (14 to 18 month-old), and suggested that the age difference in GRF responsiveness may be due to both hypothalamic and pituitary influences. Furthermore, an age-related decline in 
bovine GH synthesis in the pituitary may occur. In cattle, it has been reported that the pituitary GH content or its secretion per unit of bw decreased with increasing age and/or body size ${ }^{11,13)}$.

In the present study, neither the responsiveness of bovine GH to hGRF-44 nor the basal plasma GH level difference of sex was observed in the calves of 6-12 hours, 7 days, and 1 month of age. It has been reported that sex of the calf did not influence the basal level of serum GH during the week after birth ${ }^{32)}$. The collections of blood samples in the present experiments were carried out throughout the year. In previous studies, it has been reported that both the basal plasma GH level and the GH response to exogenous TRH in the bovine were not significantly affected by season or environmental temperature ${ }^{19,33,34)}$. In goats, it has been also reported that the concentration of $\mathrm{GH}$ in the blood remained relatively constant throughout the year, and that no correlation was found between the average weekly concentration of GH and the changes in air temperature and daylength throughout the year ${ }^{35)}$. Therefore, the data obtained in the present study seem to be not significantly influenced by sex of the experimental calves below 1 month-old and the season of blood sampling.

\section{Acknowledgements}

The authors are grateful to Professor C.H. LI, University of California, and NIAMDD, U.S.A., for their generous gift of purified bovine GH.

\section{References}

1) Hodate, K., T. Johke, A. Kawabata, S. Ohashi, M. Shiraki and S. Sawano, Jpn. J. Zootech. Sci., 55: 66-68. 1984.

2) Johke, T., K. Hodate, S. Ohashi, M. Shiraki and S. Sawano, Endocrinol. Japon., $31: 55-61.1984$

3) Moseley, W.M., L.F. Krabili, A.R. Friedman and R.F. Olsen, J. Animal Sci., 58: 430-435. 1984.

4) Della-Fera, M.A., F.C. Buonomo and C.A. Baile, Domestic Anim. Endocr., $3: 165^{-}$ 176. 1986 .

5) Hodate, K., T. Johke, A. Kawabata, H. Fuse, S. Ohashi, M. Shiraki and S. Sawano, Jpn. J. Zootech. Sci., 56 : 41-48. 1985.

6) Della-Fera, M.A., F.C. Buonomo and C.A. Baile, Domestic Anim. Endocr., 3 : 153164. 1986.

7) Hart, I.C., S. James, B.N. Perry and A.D. Simmonds, J. Endocr., 103: 173-178. 1984.

8) Hodate, K., T. Johke, A. Kawabata, H. Fuse, S. Ohashi, M. Shiraki and S. Sawano, Bull. Nat. Inst. Anim. Ind., No. 45, 13-17. 1986. (in Japanese)

9) LEUNG, F.C. and J.E. TAYLOR, Endocrinology, 113 : 1913-1915. 1983.

10) Harvey, S. and C.G. Scanes, Neuroendocrinology, $39: 314-320.1984$.

11) Trenkle, A, and D.G. Topel, J. Animal Sci., 46 : 1604-1609. 1978.

12) Machlin, L.J., M. Horino, F. Hertelendy and D.M. Kipnis, Endocrinology, 82 ; 369-376. 1968.

13) Armstrong, D.T. and W. Hansel, J. Animal Sci., 15:640-649. 1956.

14) Trenkle, A., J. Animal Sci,, 32: 115-118, 1971.

15) Siers, D.G. and L.A. Swiger, J. Animal Sci., 32 : 1229-1232. 1971.

16) Joakimsen, O. and A.K. Blom, Acta Agric. Scan., 26: 239-242. 1976. 
17) Keller, D.G., V.G. Smith, G.H. Coulter and G.J. King, Can. J. Anim. Sci., 59 : 367-373. 1979.

18) Hall, T.R., S. Harvey and A. Chadwick, Acta Endocr., 108: 479-484. 1985.

19) JoHke, T., Endocrinol. Japon., 25: 19-26. 1978.

20) Harvey, S., R.J. Sterling and J.G. Phillips, J. Endoc., 89 : 405-410. 1981.

21) Gelato, M.C. and G.R. Meririam, Ann. Rev. Physiol., 48:569-591. 1986.

22) Wehrenberg, W.B. and N. Ling, Neuroendocrinology, 37:463-466. 1983.

23) Sonntag, W.E., V.W. Hylka and J. Meites, Endocrinology, 113: 2305-2307. 1983.

24) Ohashi, S., K. Ohtaka, M. Shiraki, S. Sawano, S. Ozaki, M. Mori and T. Takaoka, Peptide Chemistry 1983, 291-296. 1984.

25) Snedecor, G.W. and W.G. Cochran, Statistical Methods, 7th ed., 83-106. The lowa State University Press. Ames, Iowa. U.S.A. 1980.

26) Coxam, V., M. - J. Davicco, F.A. Opmeer, J.P. Ravault and J.-P. Barlet, Reprod. Nutr. Dévelop., $27: 533-545.1987$.

27) Wehrenberg, W.B., Endocrinology, 118: 489-494. 1986.

28) Ohmura, E., A, Jansen, V. Chernick, J. Winter, H.G. Friesen, J. Rivier and W. VALE, Endocrinology, 114: 299-301. 1984.

29) Gluckman, P.D., J. Develop. Physiol., 6 : 509-515. 1984.

30) Shizume, K., N. Miki, M. ONo and H. Mryoshi, Folia Endocrinol. Japon., 61 (suppl.) : 992. 1985. (Abstr., in Japanese)

31) Ceda, G.P., G. Valenti, U. Butturini and A.R. Hoffman, Endocrinology, 118: 2109-2114. 1986.

32) Oxender, W.D., H.D. Hafs and W.G. Ingalls, J. Animal Sci,, 35 : 56-61. 1972.

33) Tucker, H.A. and R.P. Wettemann, Proc. Soc. Exp. Biol. Med., 151 : 623-626. 1976.

34) Joнke, T., Ann. Rep. Nat. Inst. Anim. Ind., No. 23, 109-124. 1984. (in Japanese)

35) HaRt, I.C. and H.L. Butrile, J. Endocr., 67 : 137-138. 1975.

\title{
人成長ホルモン放出因子による牛の成長ホルモン放出 におよぼす年齢の影響
}

\author{
甫立孝一 一上家 哲・川端麻夫 - 布施 洋 - 大箸信一* \\ 農林水産省畜産試験場，茨城県筑波農林研究団地 305 \\ *繊維高分子材料研究所, つくば市 305
}

合成人成長ホルモン放出因子（hGRF-44）による牛 成長ホルモン $(\mathrm{GH})$ 放出反応を比較した. hGRF-44 (体重 $\mathrm{kg}$ 当り $0.25 \mu \mathrm{g}$ ) の静脈注射前後の血液を頸静 脈カテーテルから経時的に採取し，血整 GH 濃度をラ ジオイムノアッセイで測定した。 また，hGRF-44 投与 後 90 分間の $\mathrm{GH}$ 反応曲線下の面積を测定し，このぺプ チドに反応して放出された GH の総分泌量の指標上し た. hGRF-44 注射後，いずれの場合においても，有意 な牛 GH 放出反応か観察された，6-12 時間齢から 6 力 月齢の子牛における hGRF-44に対する GH 放出反応 は，各群間で統計的に有意な違いを示さなかった。これ
に対して、12力月齢子牛の反伈は 6 力月秢子牛の反纫 に比べ有意に減少した $(\mathrm{P}<0.05)$. 同様に，24 力月数 の木経産牛の反纫は 12 力月齢子牛の反応上り有意に小 さく $(\mathrm{P}<0.05)$,さらに，48力月齢の乾乳牛の反応は 24 力月夦本経産牛の反応に比べ有意に減少した（P< 0.05)。こ㧈のの結果は，1）牛下垂体の GH 分維細胞 は出生淔後で委外因性の GRFに上く反応する機能を 持っこと，2）12 力月齢以降の牛下垂体の外因性 GRF に対する反応性は加楼に伴って隇少することを示してい る.

日畜会報, 59 (3)：285-291，1988 